\title{
Design of a discrete PID controller based on identification data for a simscape buck boost converter model
}

\author{
Mohammed Almaged, Salam Ibrahim Khather, Abdulla I. Abdulla \\ Systems and Control Engineering Department, College of Electronics Engineering, Ninevah University, Iraq
}

\begin{tabular}{|c|c|}
\hline Article Info & ABSTRACT \\
\hline $\begin{array}{l}\text { Keywords: } \\
\text { Buck Boost Converters } \\
\text { PID Controllers } \\
\text { Simscape Matlab Simulink } \\
\text { Nonlinear Systems Tuning }\end{array}$ & $\begin{array}{l}\text { This work shows the design and tuning procedure of a discrete PID controller } \\
\text { for regulating buck boost converter circuits. The buck boost converter model } \\
\text { is implemented using Simscape Matlab library without having to derive a } \\
\text { complex mathematical model. A new tuning process of digital PID } \\
\text { controllers based on identification data has been proposed. Simulation results } \\
\text { are introduced to examine the potentials of the designed controller in power } \\
\text { electronic applications and validate the capability and stability of the } \\
\text { controller under supply and load perturbations. Despite controller linearity, } \\
\text { the new approach has proved to be successful even with highly nonlinear } \\
\text { systems. The proposed controller has succeeded in rejecting all the } \\
\text { disturbances effectively and maintaining a constant output voltage from the } \\
\text { regulator. } \\
\text { Copyright }(\mathcal{C} 2019 \text { Institute of Advanced Engineering and Science. } \\
\text { All rights reserved. }\end{array}$ \\
\hline \multicolumn{2}{|l|}{ Corresponding Author: } \\
\hline \multicolumn{2}{|c|}{$\begin{array}{l}\text { Mohammed Almaged, } \\
\text { Systems and Control Engineering Department, } \\
\text { Ninevah University, } \\
\text { University Street, Ninevah, Mosul, Iraq. } \\
\text { Email: mohammed.younus@uoninevah.edu.iq }\end{array}$} \\
\hline
\end{tabular}

\section{INTRODUCTION}

Switching mode converters have been widely utilized in computer hardware, photovoltaic energy and industrial applications [1-4]. DC-DC power converters are the most efficient way to deliver a stable DC output regardless of load and input voltage variations. The classic power converters are generally classified into three topologies, buck-boost, buck and boost converters. Buck boost converter is a basic switching mode circuit in which the supplied voltage can be larger or smaller than the input source voltage level [5].

Recently, it has been a growing concern towards the development of effective control approaches to enhance the behavior of power converters. However, controlling these converters is a difficult task due to the inherited nature of nonlinearity associated with power switches [6]. Therefore, designing a controller for buck boost converter is normally accomplished by approximating the dynamic model of the system. The modeling of buck boost converter circuit has a certain amount of difficulties mainly because of the nonlinearity and time varying nature of power switches [7, 8]. Linearization of state space averaging approach is a common way of converting such time varying and nonlinear models into a good approximation linear model for buck boost converter circuit $[9,10]$. Several linear control approaches were implemented on these converters using their linear models. These techniques comprise strategies relies on classical frequency control approach such as Ziegler-Nichol and root locus [11-15]. However, most of these control theory requires precise linear mathematical models which is difficult to achieve due to parameter variation that causes a significant change in operating points, non-linearity, load and input voltage disturbances [16-18].

This paper introduces a systematic approach to construct a model for DC-DC buck boost converters using Matlab Simscape Simulink library. The method is quite useful in situations where there is no need to derive mathematical model for the plant. It will also eliminate the need for any linearization process and operating points restriction. PID is a dominate controller due to the design simplicity and good transient and 
steady state performance. Tuning PID controllers are usually accomplished by classical frequency response techniques such as root locus-type and Ziegler-Nichol approaches. This paper will show a new tuning process of digital PID controllers based on the simulation data obtained from the constructed Simscape buck boost model.

\section{CONVERTER MODELLING}

When mathematical model of the system is readily available, it is possible to employ several design approaches for calculating the parameters of the controller that will achieve the desired response of the plant. However, in most cases, the system is extremely sophisticated and highly nonlinear so that the mathematical model cannot be simply derived. Thus, an analytical approach to the controller design is not an option. To eliminate the need for any mathematical model, Matlab Simulink were introduced. This approach will not be restricted by the validity of linear mathematical model nor the small signal of the operation point. The buck boost converter is constructed using Simscape power system Simscape electrical which contains elements for developing and simulating electrical and electronic power systems. It comprises models of passive components, semiconductors and motors to build applications for various electromechanical and mechatronics systems. It can also be used in developing control systems and testing plant performance. The model of the converter constructed in Simscape electrical and power system is shown in Figure 1.

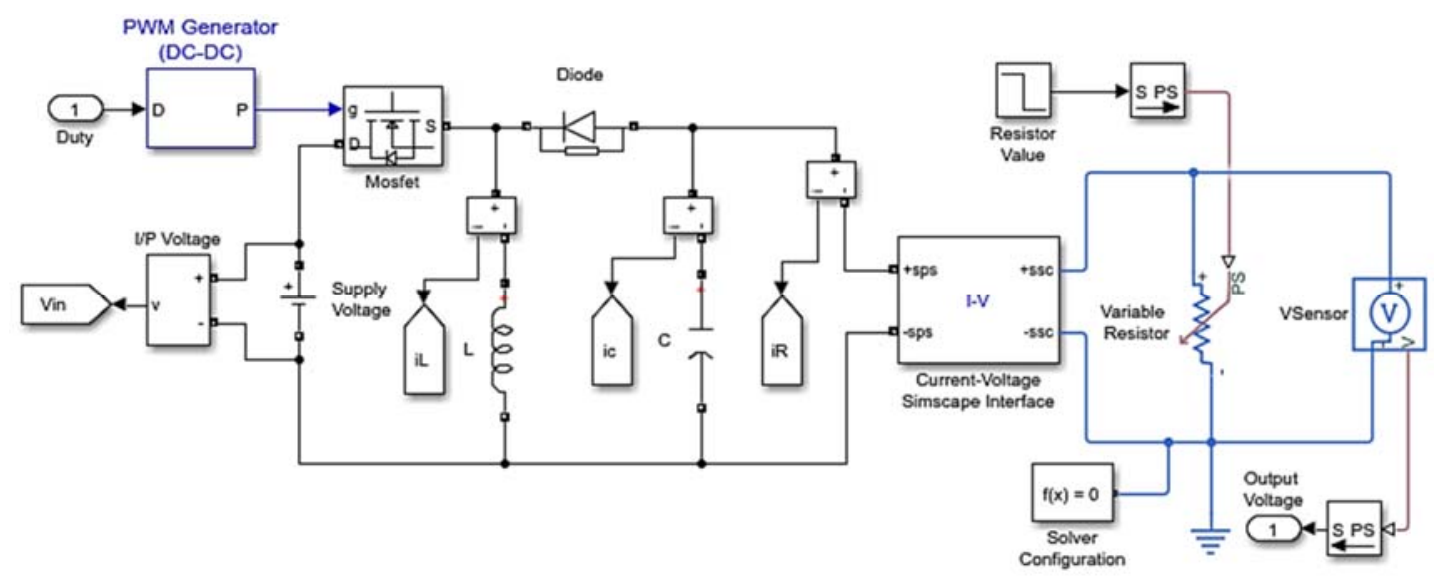

Figure 1. Buck boost converter model

Most of the components were inserted from Simscape power system library. However, the model requires using a variable resistor from Simscape electrical library. Thus, a Current-Voltage Simscape Interface block was used as an ideal coupling between Simscape Power Systems and Simscape electrical circuit. The block acts as a current source on the Simscape Power Systems side and as a voltage source on the Simscape side. The value of the components of the buck boost converter are calculated and listed in Table 1.

Table 1. Converter parameters specification

\begin{tabular}{cc} 
Parameter / Component & Value \\
Supply Voltage & $18 \mathrm{~V}$ \\
Desired Voltage Level & $12,24 \mathrm{~V}$ \\
Switching Frequency & $7800 \mathrm{~Hz}$ \\
Equivalent Load Resistor & $5 \Omega$ \\
Capacitor & $8200 \mu \mathrm{F}$ \\
Inductor & $220 \mu \mathrm{H}$ \\
Ripple & $1 \%$ \\
\hline
\end{tabular}

\section{SIMULATIONS AND RESULTS}

In Proportional Integral Derivative (PID) control systems, the desired output is compared with the actual output and the obtained error is passed to the controller to be processed. In buck boost control system, 
the output of the controller is a duty cycle which is passed to the pulse width modulation generator to produce a pulse train that drives the MOSFET power switch with adjustable duty cycle. The schematic of close loop feedback control of buck boost converter model is shown in Figure 2.

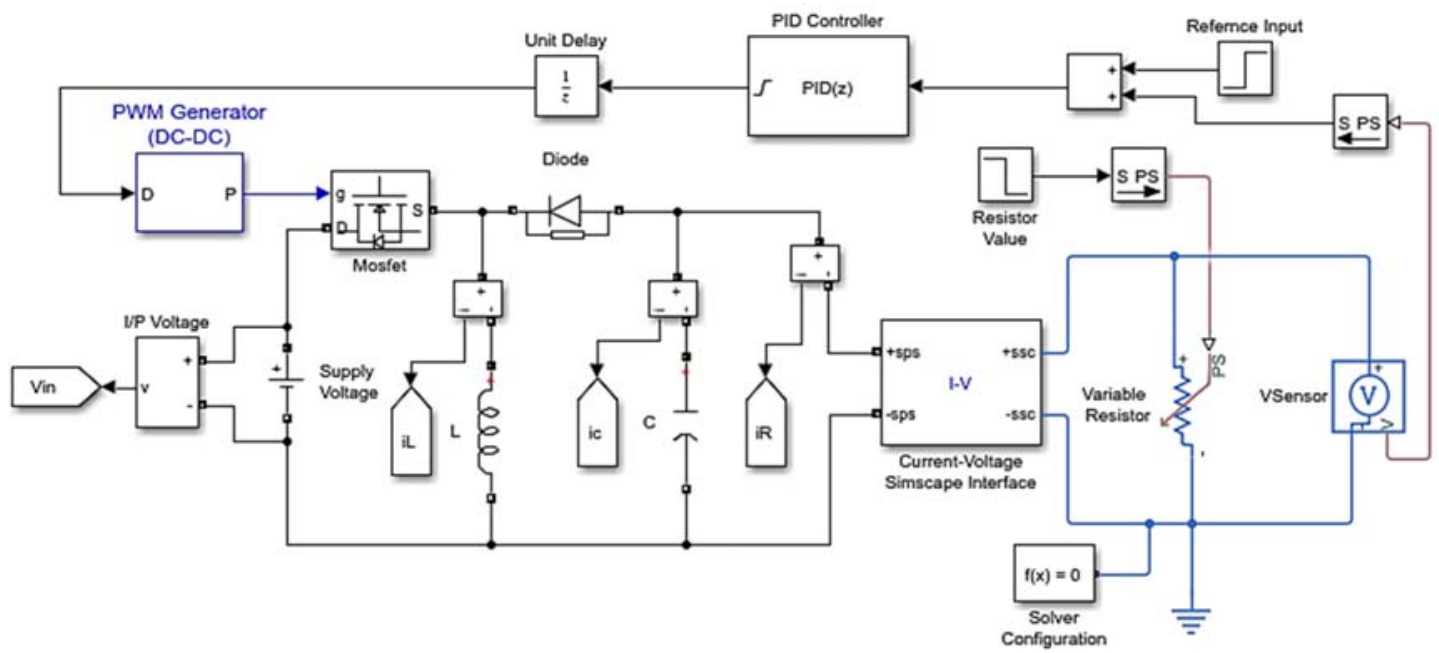

Figure 2. Feedback control schematic

As the simulation model contains high-frequency switching and thus cannot be linearized, the key challenge is to linearize the system and tune the PID gains. Thus, when clicking the tune button of the PID controller, PID Tuner will try to linearize the plant model. However, since the model has discontinuities, it linearizes to zero. Therefore, it is necessary to identify a new plant by given an input response and obtain an output data from the simulation model to build a linearized transfer function. This is achieved by temporally disconnecting the PID controller and injecting a step signal into the plant. In this configuration, the step input is given to the plant instead of the PID output while the resulting signal is fed to where the controller input used to be. Three output data responses are generated as shown in Figure 3. These are the offset response, input response and identification data. The offset response is the controller error of the offset duty cycle value (0.2). The input response is the controller error of the complete input step response signal. The identification data is the difference between the offset response and input response.

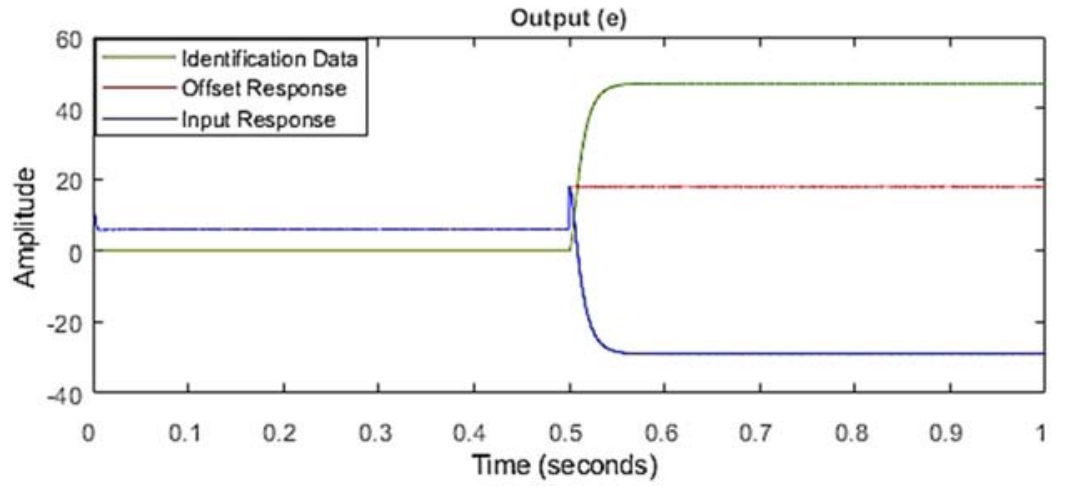

Figure 3. Output data responses

The simulation results are collected and used for system identification to identify a transfer function of the converter. Plant identification toolbox gives an option to choose different form of transfer functions. In 
this case, an under damped pair of a complex conjugates poles. The identified plant is created which matches the identified data as illustrated in Figure 4.

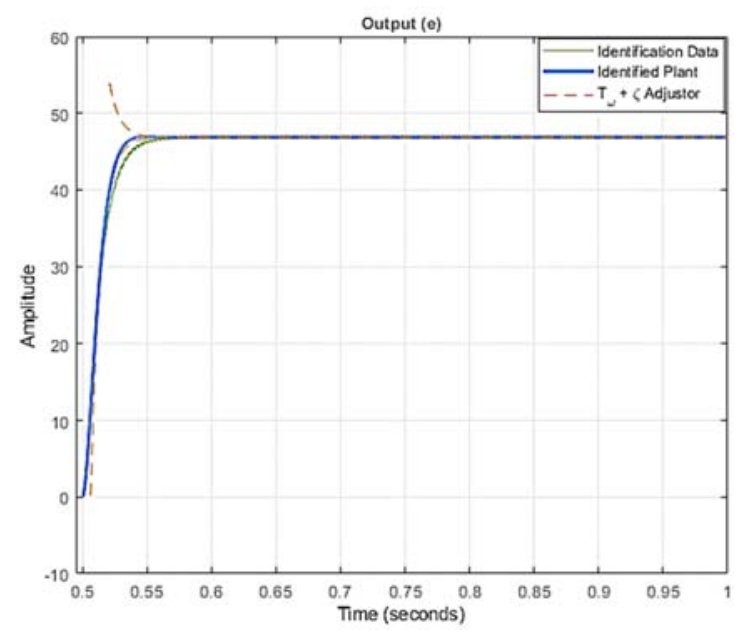

Figure 4. Identified plant structure of underdamped pole pair

Once the transfer function has been obtained, PID Tuner automatically computes PID controller gains to meet system requirements. Based on the system requirement, it is possible make the system step response, reveled in Figure 5, slower or faster as well as controlling the peak overshoot value. The following specification listed in Table 2 is adopted:

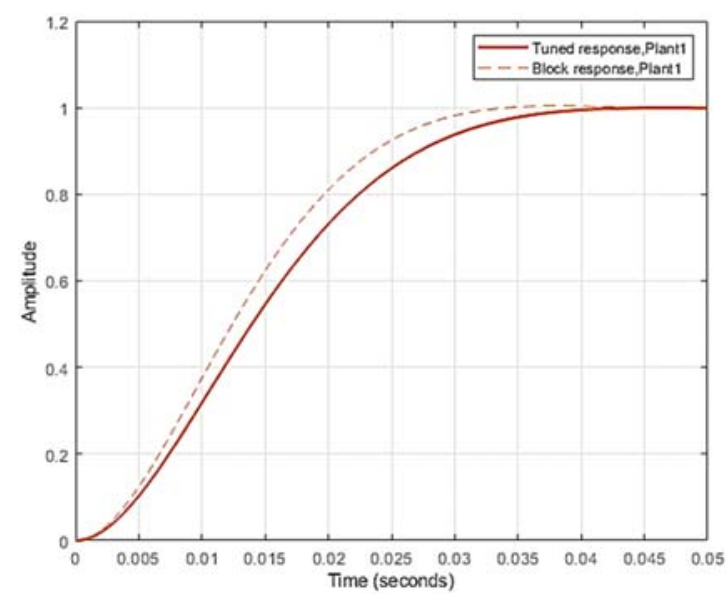

Figure 5. Tuned step response

Table 2. Specification of the transient response

\begin{tabular}{cc}
\hline Parameter & Value \\
\hline Rise time & $20 \mathrm{~ms}$ \\
Settling time & $35 \mathrm{~ms}$ \\
Overshoot & $0 \%$ \\
Gain Margin & Inf. \\
Phase Margin & $71^{\circ}$ \\
\hline
\end{tabular}


Several simulation runs are performed to validate the effectiveness of the designed controller. Figure 6 (a) reveals the output response for the buck boost converter at a constant input voltage of $18 \mathrm{~V}$ and a desired reference voltage of $12 \mathrm{~V}$. In this buck mode, an overshoot is not existent in the captured voltage response, while the rise time and settling time are approximately $70 \mathrm{~ms}$ and $100 \mathrm{~ms}$ respectively. Similarly, Figure 6(b) reveals the output response of the converter circuit for the same constant input voltage and a desired output voltage of $24 \mathrm{~V}$. The circuit will operate in boost mode and overshoot also does not appear in the output response, while the rise time and settling time are approximately $45 \mathrm{~ms}$ and $65 \mathrm{~ms}$ respectively. Figure 6(c) and Figure 6(d) show the control law signals of buck and boost modes respectively. From the obtained transient response data, it can be summarized that the converter has a faster response in boost mode operation. Also in both modes, the system shows a small difference in transient behavior in term of rise time and settling time while it reveals an exact peak overshoot value. However, the simulated system response is still close enough to the desired tuned plant response data.
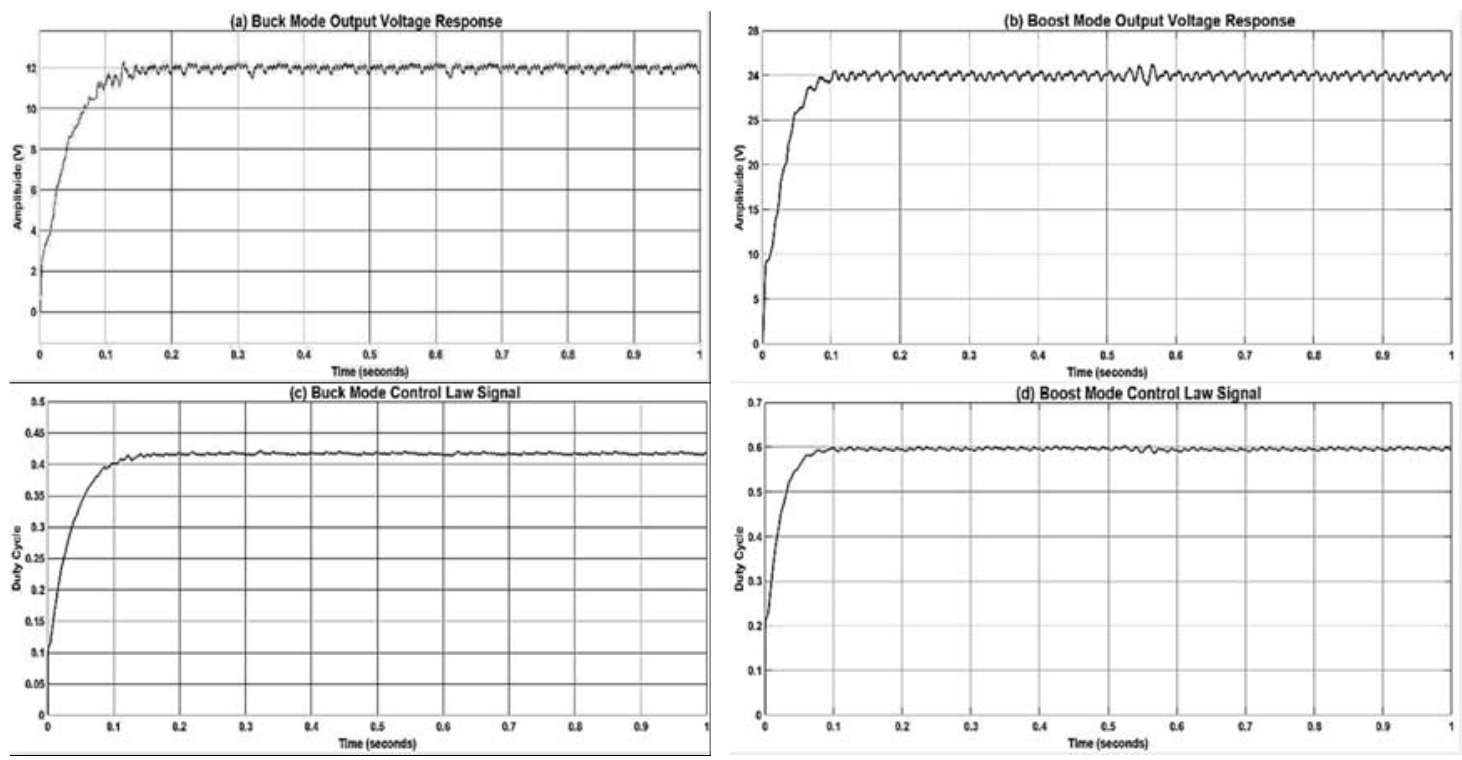

Figure 6. Output voltage responses and control law signals in buck and boost modes

To validate the capability and robustness of the controller, the response of the buck boost converter is examined under several types of disturbances. This first disturbance is a sudden change in reference voltage from 12 to $24 \mathrm{~V}$ while keeping the input voltage unchangeable at $18 \mathrm{~V}$. Figure 7 reveals the output voltage response during a sudden reference voltage change.

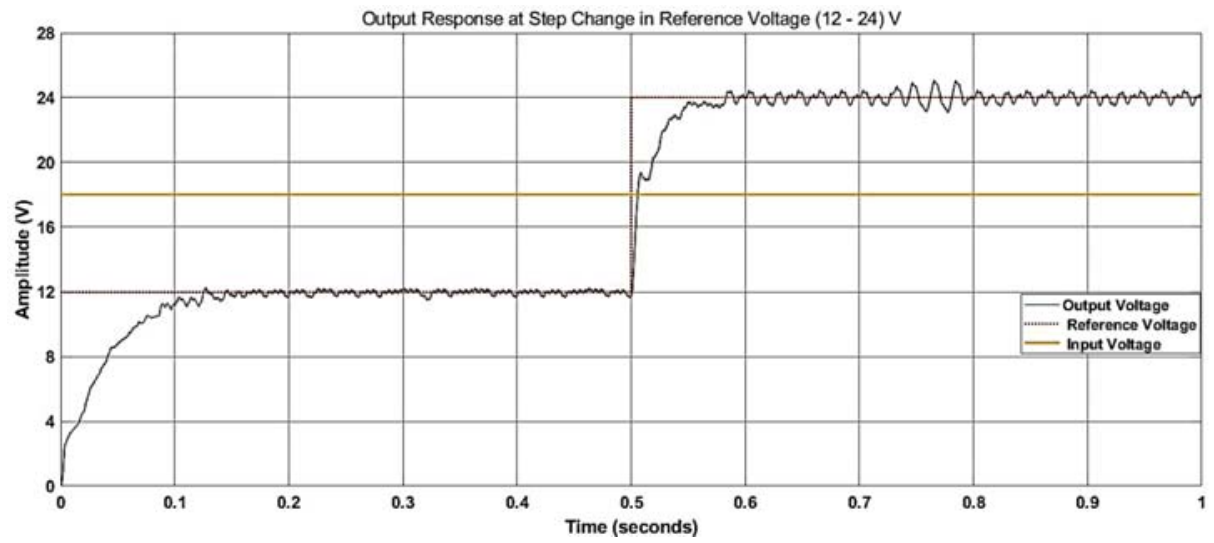

Figure7. Output voltage response at a reference voltage sudden change 
It can be clearly noticed that the response generated in the first period $(0-0.5)$ is exactly the same as the responses generated in continuous buck mode operation while as the reference voltage changes, a small difference in the rise and setting times appears in boost mode yet keeping the response overdamped. Also, the ripple in the output voltage rises as the reference voltage increase. Another test is performed to test the effectiveness of the controller by making a sharp rise in the input voltage from (18-21) V followed by sudden fall from (21-15) $\mathrm{V}$ while keeping the reference voltage constant at $12 \mathrm{~V}$ in buck mode and $24 \mathrm{~V}$ boost mode. The voltage transient behavior at step change in input voltage for both buck and boost modes are shown in Figure 8 and Figure 9 respectively.

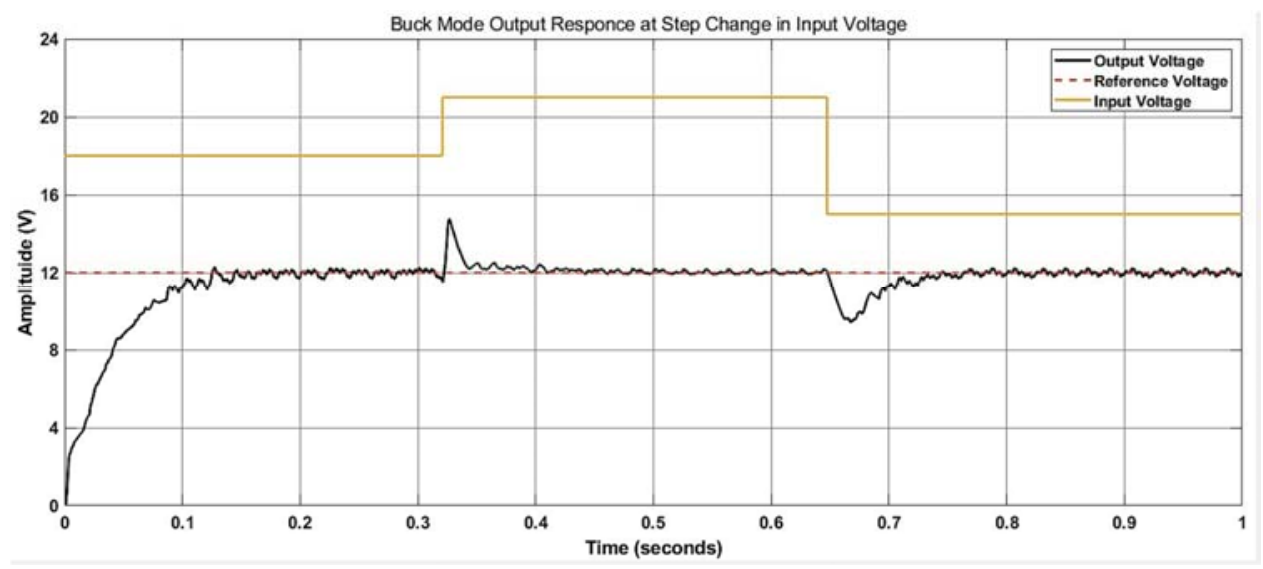

Figure 8. Buck mode output voltage response at a sudden input voltage change

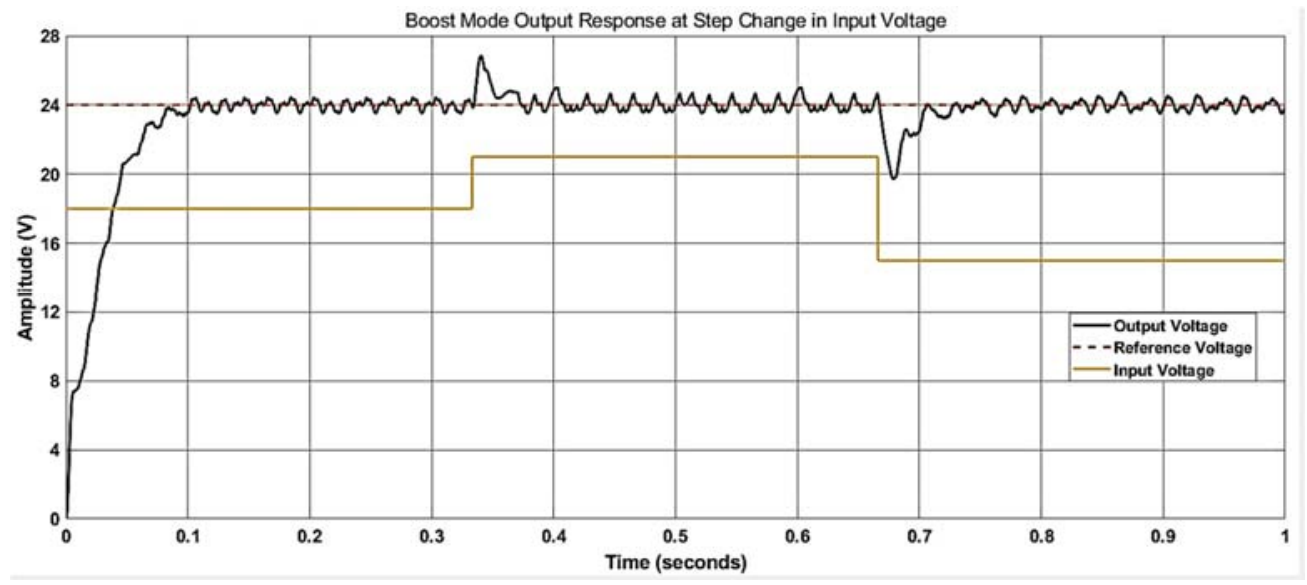

Figure 9. Boost mode output voltage response at a sudden input voltage change

It can be concluded that the controller has succeeded to make a rapid recovery of the output response to the required reference state. However, one peak has occurred at each input voltage transition and its level is proportional to the total change in the input voltage value. Finally, to test the robustness of the designed controller, load varying test is performed by suddenly changing the resistance at the output of the buck boost converter. This involves a step increase in load resistance by $30 \%$ from the nominal operating point followed by $50 \%$ a step decrease in static load, while keeping both the input and reference voltages constant. Figure 10(a) and (b) show the controller output voltage responses for step changes in load resistance at a constant input voltage of $18 \mathrm{~V}$ in both buck and boost modes. In both modes, the controller has succeeded to reject the external perturbations and maintain the output voltage unaffected. Also, the amount of ripple varies as the load current changes. Similarly, Figure 10(c) and Figure 10(d) reveal the load currents at 
variable resistance value in buck and boost modes respectively while, Figure 10(e) and Figure 10(f) show the load power variations in both modes.

a
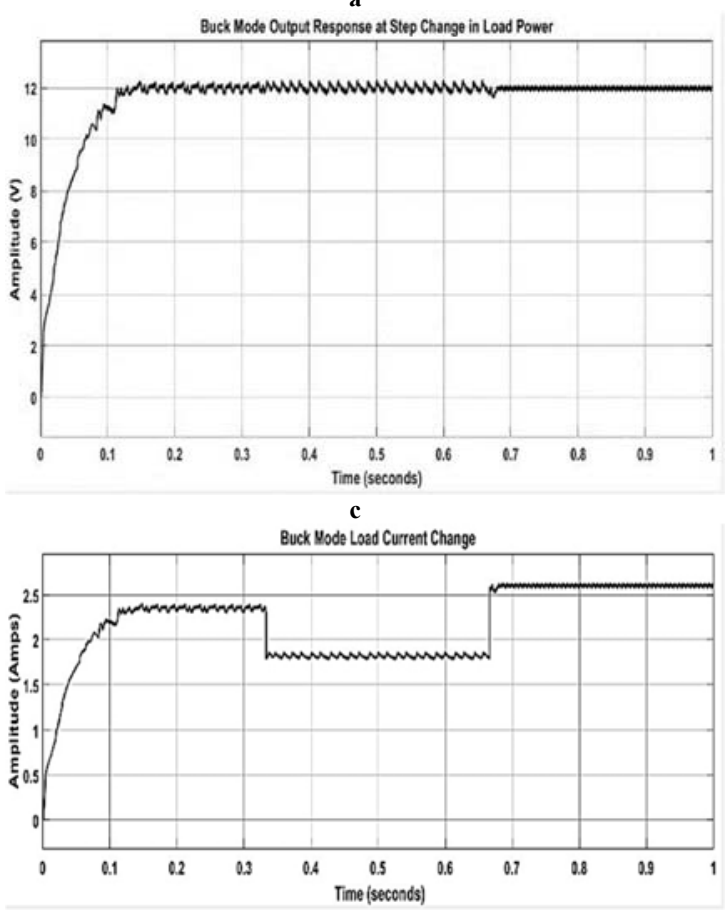

e

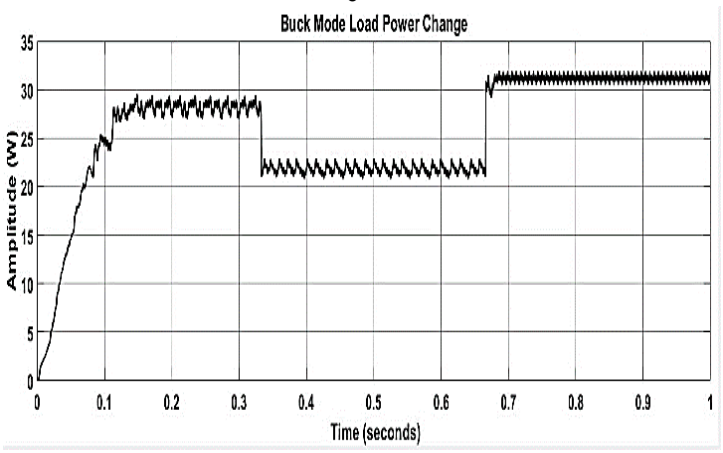

b

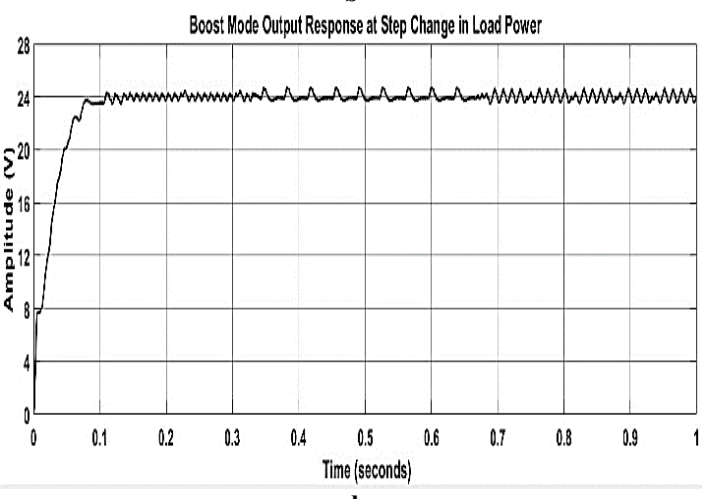

d

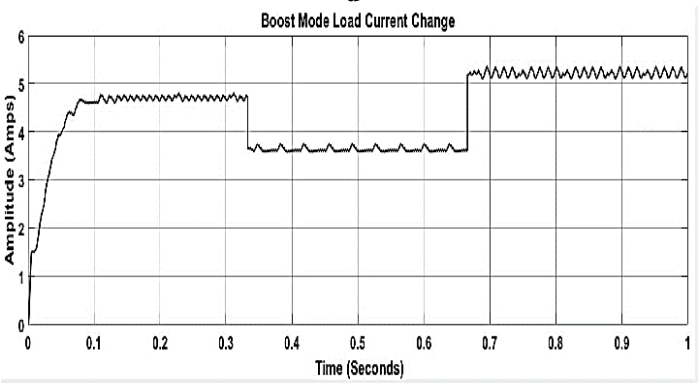

f

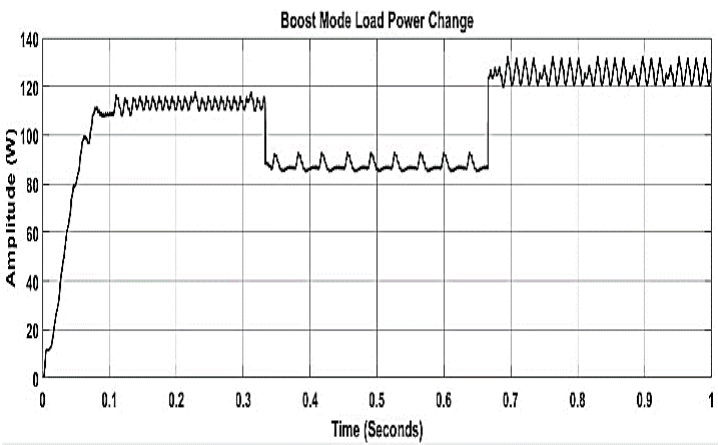

Figure 10. Output voltage responses, load current and load power variations

From the obtained results, it can be concluded that the response is outstanding since the designed controller has succeeded in rejecting all the disturbances effectively and maintaining the output voltage at the set reference state. The output response is almost the same as the response in nominal conditions with some minor differences in the rise time, setting time and ripple value.

\section{CONCLUSION}

In this paper, a new approach for designing and tuning digital PID controllers is presented for regulating DC-DC buck boost converters. The design procedure was accomplished without any need for mathematical derivation as it relies on a Matlab Simscape model instead. Under nominal condition, the controller was able to produce fast transient response and set the output voltage of the buck boost converter to the desired reference value without peak overshot and steady-state error for both buck and boost converting modes. Despite its linearity, the controller has shown a robust response under the disturbance of input and reference voltage variations and hence proves the effectiveness of the tuning method. Also, load 
varying test was performed by connecting a resistive load in series and parallel with the output load. Under load variations, the controller produced superior rise time and settling time but the ripple was higher in some cases and lower in others. In overall, the controller yielded robust response in nominal operating conditions as well as during parameter fluctuations and external perturbations.

\section{REFERENCES}

[1] S. Kaitwanidvilai, P. Olranthichachat, and M. Parnichkun, "Fixed structure robust loop shaping controller for a buck-boost converter using genetic algorithm," in Proceedings of the international Multi conference of engineers and computer scientists, 2008.

[2] M. H. Todorovic, L. Palma, and P. Enjeti, "Design of a wide input range DC-DC converter with a robust power control scheme suitable for fuel cell power conversion," in Nineteenth Annual IEEE Applied Power Electronics Conference and Exposition, 2004. APEC'04., 2004, pp. 374-379.

[3] V. Viswanatha, "Microcontroller based bidirectional buck-boost converter for photo-voltaic power plant," Journal of Electrical Systems and Information Technology, 2017.

[4] M. Kaouane, A. Boukhelifa, and A. Cheriti, "Regulated output voltage double switch Buck-Boost converter for photovoltaic energy application," International Journal of Hydrogen Energy, vol. 41, pp. 20847-20857, 2016.

[5] E. W. Zurita-Bustamante, J. Linares-Flores, E. Guzmán-Ramírez, and H. Sira-Ramírez, "A comparison between the GPI and PID controllers for the stabilization of a DC-DC "buck" converter: A field programmable gate array implementation," IEEE Transactions on Industrial Electronics, vol. 58, pp. 5251-5262, 2011.

[6] C. Elmas, O. Deperlioglu, and H. H. Sayan, "Adaptive fuzzy logic controller for DC-DC converters," Expert Systems with Applications, vol. 36, pp. 1540-1548, 2009.

[7] S. Eshtehardiha, A. Kiyoumarsi, and M. Ataei, "Optimizing LQR and pole placement to control buck converter by genetic algorithm," in 2007 International Conference on Control, Automation and Systems, 2007, pp. 2195-2200.

[8] R. Caceres, R. Rojas, and O. Camacho, "Robust PID control of a buck-boost DC-AC converter," in INTELEC. Twenty-Second International Telecommunications Energy Conference (Cat. No. 00CH37131), 2000, pp. 180-185.

[9] K. A. Tehrani, A. Amirahmadi, S. Rafiei, G. Griva, L. Barrandon, M. Hamzaoui, et al., "Design of fractional order PID controller for boost converter based on multi-objective optimization," in Proceedings of 14th International Power Electronics and Motion Control Conference EPE-PEMC 2010, 2010, pp. T3-179-T3-185.

[10] J. Mahdavi, A. Emadi, and H. Toliyat, "Application of state space averaging method to sliding mode control of PWM DC/DC converters," in IAS'97. Conference Record of the 1997 IEEE Industry Applications Conference Thirty-Second IAS Annual Meeting, 1997, pp. 820-827.

[11] S. I. Khather, M. Almaged, and A. I. Abdullah, "Fractional order based on genetic algorithm PID controller for controlling the speed of DC motors," International Journal of Engineering \& Technology, vol. 7, pp. 5386-5392, 2018.

[12] L. Guo, J. Y. Hung, and R. Nelms, "Comparative evaluation of sliding mode fuzzy controller and PID controller for a boost converter," Electric Power Systems Research, vol. 81, pp. 99-106, 2011.

[13] A. Prodic and D. Maksimovic, "Design of a digital PID regulator based on look-up tables for control of highfrequency DC-DC converters," in 2002 IEEE Workshop on Computers in Power Electronics, 2002. Proceedings, 2002, pp. 18-22.

[14] A. Kelly and K. Rinne, "Control of DC-DC converters by direct pole placement and adaptive feedforward gain adjustment," in Twentieth Annual IEEE Applied Power Electronics Conference and Exposition, 2005. APEC 2005, 2005, pp. 1970-1975.

[15] M. Namnabat, M. B. Poodeh, and S. Eshtehardiha, "Comparison the control methods in improvement the performance of the DC-DC converter," in 2007 7th Internatonal Conference on Power Electronics, 2007, pp. 246251.

[16] A. Cavallo, G. Canciello, and B. Guida, "Supervised control of buck-boost converters for aeronautical applications," Automatica, vol. 83, pp. 73-80, 2017.

[17] A. J. Koshkouei, K. J. Burnham, and A. S. Zinober, "Dynamic sliding mode control design," IEE ProceedingsControl Theory and Applications, vol. 152, pp. 392-396, 2005.

[18] L. Guo, J. Y. Hung, and R. M. Nelms, "Evaluation of DSP-based PID and fuzzy controllers for DC-DC converters," IEEE transactions on industrial electronics, vol. 56, pp. 2237-2248, 2009. 


\section{BIOGRAPHIES OF AUTHORS}

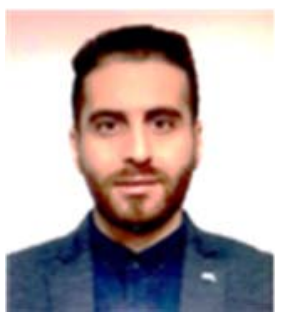

Mohammed Nussrat Younus Almaged received a BSc degree in Mechatronics Engineering from Mosul University in 2011. After the graduation, he started his career working in a power plant as a field engineer. In 2015, he achieved his MSc in Mechatronics Engineering from Newcastle University. Then, he started his academic journey working as an assistant lecturer at Ninevah University. His current research interests include advanced control strategies and optimization techniques.

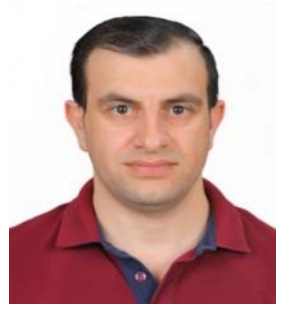

Salam Ibrahim Khather received a BSc degree in Electrical Engineering from Mosul University in 2005. In 2008, he achieved his MSc in Electrical Engineering from Mosul University. He started his career working as an Electrical Engineer in the Power Plant and Substations (20092017). Then, he started his academic journey working as an assistant lecturer at Ninevah University. His major research areas are Power and Machines, Control Systems and Power Electronics Applications.

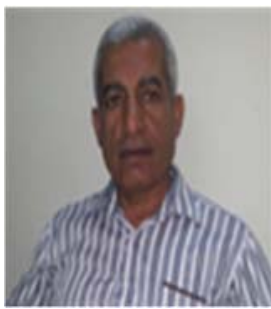

Abdullah Ibrahim Abdullah Received a BSc degree in Electrical and Electronic Engineering from Al -Rasheed Engineering and Science College in 1985. After the graduation, he started his career working as lecturer in Al-Rasheed College. In 1995, he achieved his MSc in Control Engineering from Baghdad University. Then, he started his academic journey working as a lecturer at Ninevah University. 